\title{
9
}

\section{European contact and systems of governance on Tongareva}

\section{Charlotte N. L. Chambers}

Tongareva is the northernmost and largest atoll in the Cook Islands and is often referred to as Penrhyn after the first European sighting of the atoll in 1788 when the crew of the ship Lady Penrhyn 'saw a low flat island, bearing east to north east, seven or eight miles distant'. ${ }^{1}$ The first sustained period of European contact with Tongareva occurred in January 1853 when an American brig, the Chatham, was wrecked off the south-west coast. E.H. Lamont spent a year on the island as a result of this wrecking, and later wrote an account of his time in Wild Life Among the Pacific Islanders. ${ }^{2}$ Although much coloured by the lens of the Victorian period in which it was written, this book is considered by many to be a definitive account of Polynesian life on Tongareva prior to European contact. ${ }^{3}$ The first London Missionary Society (LMS) missionaries arrived on Tongareva in 1854, shortly after the rescue of Lamont. Following the early successes of using Pacific Islanders as missionaries, in March 1854 the LMS sent three 'native teachers' to the atoll because 'the fear of being devoured is gone and

1 Watt, Lt., 1789. 'Lieutenant Watt's narrative of the return of the Lady Penrhyn transport', The Voyage of the Governor Phillip to Botany Bay, edited by Anon., 222-24, London: Stockdale, cited in P.B. Roscoe 1987. 'Of canoes and castaways: reassessing the population of Tongareva (Penrhyn Island) at contact'. Pacific Studies 11(1): 43-61, p. 244.

2 Lamont, E.H., 1867. Wild Life Among the Pacific Islanders. London: Hurst and Blackett.

3 Buck, P.H., 1932. Ethnology of Tongareva. Bulletin no. 92. Honolulu: Bernice P. Bishop Museum. 
our young men are anxious to be the first bearers of the Gospel torch among them'. ${ }^{4}$ In 1862, Tongareva was visited by Peruvian slave traders and, according to Maude's meticulous account of this period, suffered a 66.7 per cent population decrease as a result. ${ }^{5}$ When the LMS missionary Wyatt Gill visited Tongareva in 1863 he found only 40 inhabitants living in Omoka and 48 spread between the other villages. ${ }^{6}$ After the sudden population decline engendered by the slave trade, the patrilineal ariki (chief, king) structure was likely to have been highly fragmented. ${ }^{7}$ Gill, for example, reports that the remaining Tongarevans were unable to decide which remaining ariki should have prominence, suggesting that 'there is no chief whatsoever ... so that the [Christian] teacher is virtually king' ${ }^{8}$ The remaining Tongarevan population was eventually centralised into the two villages of Omoka and Te Tautua, which remain the contemporary settlements on Tongareva today.

By the late 1800s, Tongareva was involved in trading pearl shell, for which its lagoon was renowned, and the export of copra, with Omoka functioning as the main port. In 1889, after Tongareva was included in Britain's annexation of the Cook Islands, ${ }^{9}$ a body called the Hau was instituted: 'an informally constituted council of elders which was recognised as the local government' ${ }^{10}$ The Hau was designated responsibility for allowing access to the lagoon for the collection of the pearl oysters and also the management of the different motu (islets) for copra harvest. Although membership of the Hau would have likely reflected pre-existing kinship structures, Campbell notes that the Hau often had difficulties enforcing its decisions as 'their positions had, in effect, been created by the British administration' ${ }^{11}$ Campbell suggests that, at least initially, this colonial 'taint' would have affected the ability of the Hau to enforce judgements.

4 Buzacott, 1866. Mission life in the islands of the Pacific, cited in A.R.T. Campbell, 1985. Social Relations in Ancient Tongareva. Pacific Anthropological Records no. 36. Honolulu: Bernice P. Bishop Museum, p. 10.

5 Maude, H.E., 1981. Slavers in Paradise: The Peruvian Slave Trade in Polynesia, 1862-1864. Canberra: Australian National University Press.

6 Maude, 1981, p. 10.

7 Campbell, 1985.

8 Gill, 1887, cited in Campbell, 1985, p. 80.

9 See Gilson, R., 1980. The Cook Islands 1820-1963. Wellington: Victoria University Press.

10 Campbell, 1985, p. 13.

11 Campbell, 1985, p. 14. 
The Hau on Tongareva was replaced by the island council in 1901, which comprised of six elected members: three members taken from the settlements at Omoka and Te Tautua respectively, two ariki, and the colonial resident agent, who functioned as president. ${ }^{12}$ The island councils were empowered by the colonial administration to take on the role of mediator and manager of the trade relations by making local ordinances or by-laws. Only four such by-laws were established, between 1901 and 1965, in order to deal with issues of wandering pigs and the use of obscene language. ${ }^{13}$ The island council could also use its ordinance powers to impose rahui over the gathering of copra and pearl shell.

The ability of island councils to establish by-laws for the island continued unchanged by the Cook Islands Act 1915. In the Cook Islands Amendment Act 1957, however, by-laws made by island councils were subject to approval by the high commissioner; thus, Section 51.3 of the Act reads: 'no by-law made by an Island Council shall become law until it has been assented to by the High Commissioner' ${ }^{14}$ In the Cook Islands Outer Islands Act 1987, there remains a clear hierarchy of decision-making powers, although any by-law made by island councils must first be approved by a national executive council in Rarotonga before eventually attaining the approval of the relevant member of parliament for the island and, finally, ratification by parliament. The present functions of island councils, then, are slightly ambiguous in that they enjoy relative autonomy in the outer island context, yet still require centralised government approval for the establishment of any by-laws.

As a consequence Tongareva, as an outer island, has a system of governance that is at once 'local' but also clearly associated with legislative priorities of the central government based in Rarotonga. Indeed, while those distant from Tongareva may construct the island council as an effective structure reflecting 'local' interest and needs, this belies the varying social, political and cultural differences that the island council must negotiate in producing local decisions and

12 Campbell, 1985.

13 Crocombe, R.G., 1964. Land Tenure in the Cook Islands, Oxford University Press.

14 See www.paclii.org/cgi-bin/sinodisp/ck/legis/ck-nz_act/ciaa1957212/index.html?stem= \&synonyms $=\&$ query $=$ Cook $\% 20$ Islands $\% 20$ amendment $\% 20$ act $\% 201957$. 
courses of action. ${ }^{15}$ The colonial origins of the Tongarevan Island Council and its current relationship to both local and national structures of authority are important for understanding the varying levels of authority and respect garnered by the island council in its contemporary manifestation. This is particularly so with regard to its ability to institute rahui.

\section{The use of rahui on Tongareva}

Rahui or the Rarotonga equivalent, ra'ui, is a technique used by those in power to control or deny access to land, crops or areas of the sea. ${ }^{16}$ Rahui were generally declared in response to declining resources, or to protect scarce resources from over-harvest. ${ }^{17}$ Rahui works by 'bounding' or 'closing' physical areas, for example, motu in the case of copra, or areas of the lagoon in the case of pearl shell. These areas are protected by the invocation of tapu so that those who disobey or break rahui are subject to either physical or spiritual sanctions. ${ }^{18}$ Tiraa discusses how on the southern Cook Island of Atiu, in pre-European contact times, punishments for breaking rahui could be as severe as execution, banishment or having one's house and other property destroyed. ${ }^{19}$ Throughout the Cook Islands, breaking rahui was generally expected to be dealt with by community pressure or, in postcontact times, by sanctions imposed by the relevant island council. ${ }^{20}$

The fact that the practice of rahui remains in use on Tongareva is not insignificant, particularly as its use was legislated against in the Cook Islands through the $1908 \mathrm{Te}$ Mana Ra'ui Act, which declared that 'the ancient right of $\mathrm{ra}^{\prime}$ ui no longer existed in respect of any land which has been investigated by the Native Land Court'.$^{21}$ Moreover, that rahui continues to be used in a marine context is interesting given that the

15 See Robbins, P., 1998. 'Authority and environment: institutional landscapes in Rajasthan, India'. Annals of the Association of American Geographers 88(3): 410-35.

16 Crocombe, 1964.

17 Ama, A., 2003, 'Maeva - rites of passage: the highlights of family life'. In R. Crocombe \& M.T. Crocombe (eds), Akono'anga Maori: Cook Islands Culture. Suva: University of the South Pacific, pp. 119-26.

18 Gilson, 1980.

19 Tiraa, A., 2006. 'Ra'ui in the Cook Islands - today's context in Rarotonga'. SPC Traditional Marine Resource Management and Knowledge Information Bulletin 19: 11-15.

20 Gilson, 1980.

21 Crocombe, 1964, p. 325. 
1915 Act stipulated that '[n]ative customary title shall not extend ... to any land below the high-water mark'.$^{22}$ Indeed, it appears that the isolated nature of the outer islands, such as Tongareva, combined with decentralised governance through island councils, has meant that these islands enjoy relative independence in their decision-making processes, one aspect of which is the persistence of rahui.

The survival of rahui also suggests something of its flexibility as a technique in responding to the changing situations and circumstances of the island as well as the ability of the islanders to make the most out of the cracks of recognition that continued to exist in the superimposed colonial systems. In pre-European contact times, rahui was a largely decentralised tool used by individual families on a day-to-day basis to protect coconut crops. ${ }^{23}$ Lamont also notes, however, that there were instances where large-scale bans (what he terms masanga - synonym for rahui) were imposed by ariki and taura (priests) with the agreement of the huaanga (a ramage comprising a group of patrilineal extended families) in order to prevent starvation. As Lamont's account states:

To 'masanga' or put a ban on certain trees ... is a matter of every-day occurrence with the economic landowner, that the supply of nuts may not fail, but to have the ban put on every tree throughout the island, and to be reduced to a very moderate allowance of food, was soon the case of great suffering ... After a great deal of talking on the part of the natives [sic] with their usual excitement, the restrictions of the masanga were finally agreed to among themselves, and all the men placed around their necks a piece of platted sinnet as a badge of their acceptance of it. ${ }^{24}$

This masanga was devised in order to allow the coconuts on food lands to recover from over-harvesting. Yet, such was the dependency of the people on coconut, a decision not to exploit the resource located on their motu meant pressure to raid the coconut plantations on motu belonging to other huaanga around the island. In this case, then, a decision to protect and regenerate local coconut supplies through a ban on use resulted in conflict with surrounding groups. Such a drastic step thus required the consent of the whole huaanga

22 Crocombe, 1964, part 12, sec. 419.

23 Lamont, 1867.

24 Lamont, 1867, pp. 273-74. 
as the consequences were far-reaching. ${ }^{25}$ So important was longer term preservation of resources that huaanga contemplating rahui were willing to risk conflict with neighbouring huaanga and drastic reduction of food supplies.

Post-contact, with a growing reliance on imported goods, the emphasis was placed on protecting the resources (pearl shell and copra) that fell at the centre of the newly established trade relations upon which island income depended. ${ }^{26}$ According to people interviewed during my fieldwork, rahui was also used to declare certain parts of the lagoon closed in order to allow pearl shell to replenish, with the last instance of this type of rahui occurring in the mid-1990s. ${ }^{27}$

The way in which the Tongarevan people adapted practices such as rahui to the economic and social changes brought about by European contact is noteworthy. On the one hand, despite the seemingly negative hegemonic influence of the LMS missionaries and the colonial presence on Tongareva, the people were not simply passive in their reception of these forces and responded actively instead, modifying them to suit their purposes. These observations relate to a specific pragmatism noted by other scholars in relation to the alacrity with which Christianity, as one particular consequence of European contact, was adopted throughout the Pacific Islands. For example, writing with respect to the rapid conversion to the LMS-inspired Christian faith that spread rapidly throughout the Cook Islands, Buck notes that 'material benefit was associated with the new religion and, if such benefits could be obtained more readily by adopting that religion, why not adopt it? ${ }^{28}$ Cowling goes on to cite the LMS missionary John Williams, who made clear the relationship between missionisation and the subsequent expansion of commercial interests: 'Thus, wherever the missionary goes, new channels are cut for the streams of commerce' ${ }^{29}$ This, however, is not to imply that the Tongarevan people had total agency, as the 1915 Cook Islands Act

\footnotetext{
25 Buck, 1932.

26 Buck, 1932.

27 Papa R., pers. comm. with the author, 24 May 2006.

28 Buck, 1939. Cited in W. Cowling, 2006. 'Once you saw them, now you don't - the disappearance of Cook Island traditional craft production'. Proceedings from the 2 nd International Small Island Cultures Conference. Sydney: Maquarie University Press, p. 30.

29 Williams, 1837. Cited in Cowling, 2006, p. 30.
} 
best demonstrates. Nevertheless, the continued use of rahui suggests flexibility in terms of what such a designation could be applied to, although the basic premise of the technique remained unchanged.

In this respect, Hviding notes that customary mechanisms such as rahui can be characterised on the basis of their flexibility and their ability to be applied to changing situations and circumstances. ${ }^{30}$ Although Hviding's comments pertain to a Melanesian context, he suggests with regard to the use of customary marine tenure (CMT) systems, that the success of CMT structures to adapt to change lies precisely in their unwritten and non-codified nature. This characteristic, he asserts, enables such systems to retain the capacity to rapidly adapt to any sudden changes that might occur, be it in terms of changes to usage patterns or ecological conditions. CMT systems are, therefore, able to perform 'functions in the modern context for which they were not designed' ${ }^{31}$ With respect to imposing closures on resources, Hviding further states that closures may not necessarily reflect absolute states of abundance or scarcity of a resource, but rather can be influenced by the 'perception of market prices, available transport and other factors that affect the demand for and number of potential harvests of the resource in question'. ${ }^{32}$

It appears, then, that there are many similarities between Hviding's perception of CMT systems and the flexibility in the way that rahui as a technique was used and adapted in the changing Tongarevan context. Moreover, although the structures by which rahui could be imposed changed from dispersed kin groups to a centralised island council, the island council system continues to depend on input from the Tongarevan people. Indeed, the inclusive structure of the island council, and the way rahui requires the agreement of the people it is attempting to manage in order to work, function to ensure it is a management tool that cannot simply be coopted by whoever is in power.

30 Hviding, E., 1998. 'Contextual flexibility: present status and future of customary marine tenure in Solomon Islands'. Ocean and Coastal Management 40: 253-69.

31 Polunin, 1984. Cited in Hviding, 1998, p. 255.

32 Hviding, 1998, p. 263. See also Chambers, C.N.L., 2008a. 'Bounding the Lagoon: Spatialising Practices and the Politics of Rahui, Tongareva, Cook Islands'. PhD thesis, University of Edinburgh. 


\section{Authorising rahui}

In an interview with Papa M, I was given an eloquent description of the use of rahui when Tongareva was still involved in the copra trade. The use of rahui to close down motu around Tongareva was functioning up until the early 1980s and was used in order to allow the coconuts to replenish before the next harvest. Papa M's comments are significant, for they show how people were literally 'called in' to observe the rahui placed on particular motu:

I recall I was a young boy, the rahui was still enforced over here. I still remember the time when the papa would come, an old man, with a paatee [slit drum], making a noise, calling out 'the rahui, the rahui', and the name of the motu that would be closed. He tried to make everyone aware that there would be a rahui. Then there would be a public notice put up by the island council. Everybody knew there would be a rahui. And if the rahui is enforced, no one was allowed to go over to that island. As a kid here, I know, I still remember, the time when we go [to the island], everybody would say a prayer. A prayer for the rahui to close, and then, for the rahui to open. ${ }^{33}$

As this quote from Papa M illustrates, the ability to 'call' the rahui was contingent on the whole community first being aware of the planned closure and second, abiding by the spiritually enforced sanctions, physically enacted by the people going to the site of the rahui and participating in prayer. Implied in his account is a community-wide recognition of the mana (respect, authority) of the elders who would call in the rahui and, in turn, respect for the tapu nature of the closed motu. As Papa $\mathrm{M}$ testifies, the rahui would start by producing a closure not just on the coconuts, but on physical access to the motu in question. This bounding of both resource and surrounding area as tapu was achieved by the imposition of a normative rule that, while relying on community recognition and adherence, also depended on the tacit recognition of the authority of the island council as the appropriate body to make such declarations and as having the right to punish those who disobeyed. Once the period of rahui was over, a prayer was again used to unbound the motu and open up the resource, once again allowing people to enter the area of land and harvest coconuts for copra. In terms of how the rahui works, then, the island council

33 Interview with the author, 24 May 2006. 
played a key role in terms of adjudicating the need for rahui, where this rahui was to be located, and how long it would last. This role, at least according to Papa M's account, was endorsed by Tongarevan society more generally.

Comments made by other interviewees suggest a considerable shift between how Papa M recalled rahui to have worked in the past and the implications of placing a rahui on pasua at the time of my fieldwork. Instead of the ritualised 'calling in' of the rahui of old, and the clear and unproblematic obedience to the bounded motu and resource in question, other people suggested that placing rahui on pasua now would be problematic and difficult to enforce. In a group interview, for example, Papa $\mathrm{T}$ and his friend Papa $\mathrm{J}$ debated this point:

Papa J: Well for the pasua, and how they are thinking of closing it now? I remember the last time, about 10 or 15 years ago, we started closing the shell, the mother pearl shell. They [the island council] closed the lagoon for two years. You know what happened? They never put someone in charge or whatever. People to look after the rahui. And by the time it came to open the lagoon, there was no shell! What was the point of closing it! What was the point? If they want to close it again now for the pasua, they need to get everyone, or select a team, make them police the boundary of the rahui ...

Charlie: And monitor it?

Papa J: And monitor it, yeah.

Papa T: But the main thing with the pasua, they cannot close the pasua without the people's say.

Papa J: That's what I said before!

Papa T: Yes, they cannot do it.

Charlie: Because people won't listen?

Papa T: It is the people who will say close the lagoon or keep it open. It's the people who say. Not the council..$^{34}$

Papa T's comments hint at a considerable shift in the authority vested in the island council. He emphasises the need to have 'the people' involved in deciding whether or not to 'close the lagoon or keep it

34 Group interview with the author, 16 May 2006. 
open'. Moreover, if a closure was instated by the council alone, without the people's say, Papa J suggests that it would fail if it didn't also have people involved to monitor and enforce compliance. Indeed, concurrent with Papa J and Papa T's comments, it was not uncommon for people to suggest that a rahui on pasua would fail if it wasn't supported by the island populace as a whole. In the following interview, for example, Mama $\mathrm{T}$ questions how the island council would be able to enforce the proposed closure on the lagoon:

Charlie: Do you think people will respect rahui now?

Mama T: If it's a by-law. Only if it's going to be a by-law. If it's going to be a verbal meeting in the island council chamber over here, no. If it's just a notice up on the notice board there, that the council is saying there is no more pasua for selling, people won't listen. People will just ignore that notice. But they will respect it if it's a by-law. Because a by-law will give the police the right to check people's boats and follow it up. Only if it's a by-law. If it's just a verbal thing, people won't give a damn. They won't listen. ${ }^{35}$

Mama T's comments, echoing again the frustrations expressed by Papa J and Papa T, suggest that it would only be through legal means, by the island council generating a by-law for the police to enforce, that people would adhere to a rahui on pasua. Neither the power of the designation of tapu, nor a 'verbal meeting', nor even a 'notice' appear enough to guarantee compliance with the restricted access planned for the lagoon. Mama T's comments suggest that rahui needs to be combined with alternatively authorised structures, that of the by-law, to be effective. While the Tongarevan Island Council has, since its inception, had the legislative power to make by-laws, it appears that rahui has never previously required formalisation in the form of a by-law in order for it to be effective on Tongareva. Making the rahui a by-law would, as Mama $\mathrm{T}$ suggests, make the enforcement of the rahui a matter for the police, and in turn anyone who broke the rahui would be punishable by law. The implication of Papa J, Papa T and Mama T's comments is that the council lacks the ability to monitor and enforce rahui in relation to pasua. This suggests a significant change in the ability of the island council to effectively govern the marine environment in the current Tongarevan context. 
The relationship between authority and rahui in contemporary contexts is not unique to Tongareva. Writing with regard to the recently re-established ra'ui on Rarotonga, Tiraa echoes the concerns of Mama $\mathrm{T}$ that the Koutu Nui, a formalised group of mataiapo (lesser chief), which sit underneath the House of Ariki, have lost the ability to punish people who fail to observe the five ra'ui areas established around the island. ${ }^{36}$ There is ongoing debate on Rarotonga as to whether the various ra'ui could be given legal recognition under the Environment Act 2003, which would make the ra'ui a matter for the Ministry of Marine Resources and give the police powers to punish those who break it. Many support this proposal so as to limit the number of infringements and thus to increase the effectiveness of the ra'ui in protecting the marine environment. While some members of the Koutu Nui are supportive of this plan, other members see the lack of respect for ra'ui as a lack of respect for the mana of the traditional leaders. They feel that giving ra'ui a legal basis would further erode this respect as it would foster an approach to conservation learnt by fear rather than by traditional conventions of mana and tapu. ${ }^{37}$

\section{Conclusion}

The debates concerning the rahui on pasua at the time of my fieldwork speak to the complex relationships that surround practices of rahui and the structures of authority upon which they depend. In the Tongarevan context, contrasts in views concerning how rahui worked in the past with people's concerns as to how it might fail in the present, suggest that there is an important relationship between changing levels of respect accorded the contemporary Tongareva Island Council and the debates for and against a rahui on pasua. Indeed, residents such as Mama T appear to be pushing for a 'hybrid' rahui, one that still works on traditional principals, but has the added strength of legal protection in order to garner the necessary compliance.

Changes associated with missionisation and colonisation then, although changing the socio-spatial structures of authority in relation to land and resources, did not simply 'obliterate' pre-European contact

\footnotetext{
36 Tiraa, 2006.

37 Tiraa, 2006, p. 13.
} 
knowledges and practices. Indeed, there were specific legal provisions for recognising these relationships and interests. Particularly in the outer island context of Tongareva, the island council was able to function in a relatively independent, though not locally uncontested, manner. Rahui, as a key 'tool' of the island council, survives as an example of 'traditional' knowledge and management practice in relation to land, water and resources. Rahui, however, is also a 'modern' product in that it is a form of governing resources that sits within a radically socio-spatially restructured Tongareva. In this regard, tradition, contra to the way in which it is commonly deployed as the binary opposite to the modern, is not meant to imply a state of fixity, of that which is unchanging or 'rooted'. Rather, as this article has briefly explored, tradition as invoked by the people of Tongareva in the context of rahui is inherently dynamic, mutable and ongoing in its negotiation today. ${ }^{38}$

38 I would like to thank the people from Tongareva who participated in my research as well as assistance from Dr Andrea Nightingale and Professor Jane Jacobs at the University of Edinburgh. 
This text is taken from The Rahui: Legal pluralism in Polynesian traditional management of resources and territories, edited by Tamatoa Bambridge, published 2016 by ANU Press, The Australian National University, Canberra, Australia. 